\title{
Role of Vitamin D Glucosiduronate in
}

\section{Calcium Homeostasis}

\author{
Sreeramulu Nagubandi, Rajiv Kumar, James M. Londowski, R. A. Corradino, \\ and Pamela S. TIETz, Endocrine Research Unit, Department of Medicine, \\ Mayo Clinic and Foundation, Rochester, Minnesota 55901; \\ Department of Physical Biology/Section of Physiology, New York State College \\ of Veterinary Medicine, Cornell University, Ithaca, New York 14853
}

A B S T R A C T Evidence has been presented suggesting the presence of vitamin $D_{3} 3 \beta$-glucosiduronate and 1,25-dihydroxyvitamin $\mathrm{D}_{3}$ glucosiduronate in rat bile. To evaluate the role of vitamin $\mathrm{D}$ glucosiduronates in calcium and phosphorus homeostasis, we synthesized vitamin $D_{3} 3 \beta$-glucosiduronate and tested its biological activity in calcium- and vitamin D-deficient rats. After the intravenous administration of vitamin $D_{3} 3 \beta$-glucosiduronate to rats maintained on a low calcium diet, there was an increase in duodenal calcium transport and an increase in serum calcium. Vitamin $D_{3} 3 \beta$-glucosiduronate, however, was less active than equimolar amounts of vitamin $D_{3}$. At doses of less than 0.65-1 nmol per rat, the conjugate exhibited no activity. When vitamin $D_{3} 3 \beta$-glucosiduronate was administered to vitamin $\mathrm{D}$-deficient rats, 25 -hydroxyvitamin $\mathrm{D}$ was detected in the serum; the increase in serum 25-hydroxyvitamin $D$ levels was less than that observed after the administration of an equimolar amount of vitamin $D_{3}$. Vitamin $D_{3} 3 \beta$-glucosiduronate showed no detectable activity in the induction of calcium binding protein in chick embryonic duodena, a system in which no endogenous steroid $\beta$-glucuronidase activity is detectable. These data demonstrate that vitamin $D_{3} 3 \beta$-glucosiduronate is biologically active in vivo and that the observed activity is due to hydrolysis of the conjugate to vitamin $D_{3}$. As vitamin $D_{3} 3 \beta$-glucosiduronate is excreted in the bile of rats, it is possible that this conjugate is reutilized in vivo after hydrolysis to free vitamin $D_{3}$. These results suggest the existence of a mechanism for reutilization of the biliary products of vitamin $D_{3}$.

\section{INTRODUCTION}

To act physiologically vitamin $\mathrm{D}$ must be metabolized to 25-hydroxyvitamin $D_{3}$ in the liver and then to 1,25 -

\footnotetext{
Address reprint requests to Dr. Kumar at the Mayo Clinic.

Received for publication 19 March 1980 and in revised form 8 August 1980.
}

dihydroxyvitamin $D_{3}$ in the kidney (1). The peripheral metabolism of vitamin D homologues, however has received little attention. Evidence has been presented to show that at least one vitamin $D_{3}$ homologue, 1,25dihydroxyvitamin $D_{3}$, is metabolized in several ways (2-4). Furthermore, there is strong evidence to suggest that the biliary route of excretion is an important pathway in the metabolism of several vitamin $D_{3}$ compounds (5-9). We have recently shown that products of 1,25-dihydroxyvitamin $\mathrm{D}_{3}(5)$ and 24,25-dihydroxyvitamin $D_{3}(6)$ are excreted in bile as polar compounds, reabsorbed in the intestine, and re-excreted in bile. It is likely that one of the metabolites present in bile is a glucosiduronate of 1,25-dihydroxyvitamin $D_{3}(5)$. Earlier, Bell and Kodicek (7) demonstrated that vitamin $D_{3} 3 \beta$-glucosiduronate was probably excreted in rat bile. Therefore, glucuronides of at least two vitamin $D_{3}$ homologues are known to exist in vivo.

There are several unresolved questions concerning the metabolism of vitamin D homologue glucosiduronates: Do these compounds have biological activity? If so, are they active per se or do they need to be hydrolyzed to the parent vitamin $\mathrm{D}_{3}$ homologue? Is it possible that the biliary excretion and subsequent reabsorption of these compounds in the intestine is a mechanism whereby the organism can conserve vitamin $D_{3}$ and thus prevent rapid depletion of this vitamin? To answer these questions we synthesized vitamin $D_{3}$ $3 \beta$-glucosiduronate and tested its biological activity in vitamin $\mathrm{D}$-deficient rats in vivo.

\section{METHODS}

General. Ultraviolet spectra were taken in ethanol with a Beckman model 25 recording spectrophotometer (Beckman Instruments, Inc., Fullerton, Calif.). Mass spectra were recorded on spectrometer HP model 5985a GC/MS (HewlettPackard Co., Palo Alto, Calif.) equipped with a direct insertion probe. Helium was used as carrier gas. Spectra were recorded at a source temperature of $150^{\circ} \mathrm{C}$. High performance liquid 


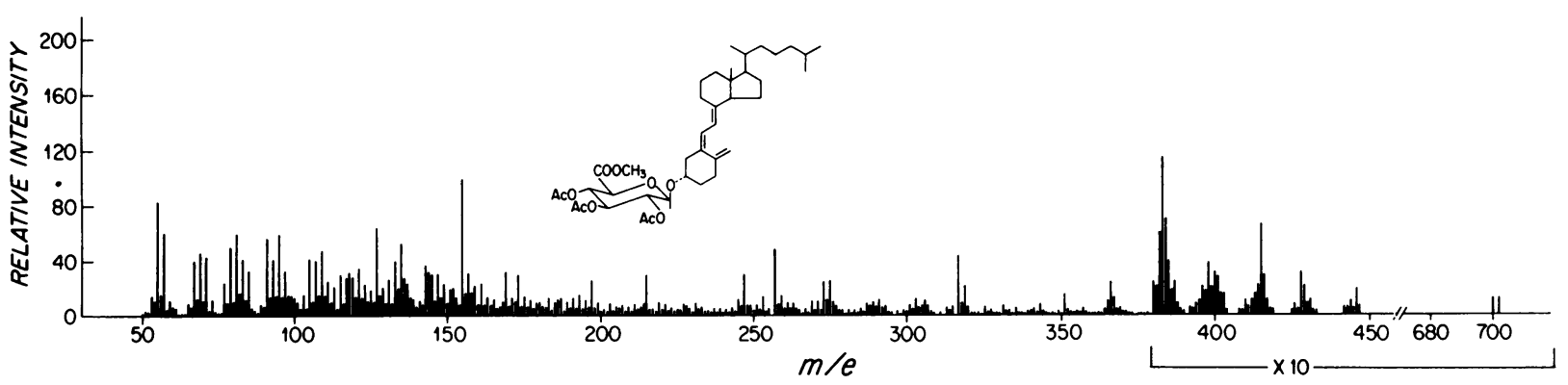

FIGURE 1 Mass spectrum of vitamin $D_{3}$ triacetoxy glucuronide methylester.

chromatography (HPLC) ${ }^{1}$ was performed on a Waters Associates, Inc., (Milford, Mass.) chromatograph, equipped with a U-6-K injector, a programmable solvent delivery system and a model 450 variable wavelength detector set at $265 \mathrm{~nm}$. Radioactivity was determined with a Beckman LS9000 $\beta$-scintillation counter.

Animals. Male, albino, weanling rats (50-60 g) were obtained from Holtzman Co. (Madison, Wis.) and maintained on vitamin D-deficient synthetic diets containing $0.02 \%$ calcium, $0.4 \%$ phosphorus or $1.2 \%$ calcium, $0.1 \%$ phosphorus. The animals were used for experiments when they were $4 \mathrm{wk}$ postweaning, and when active transport of calcium in the duodenum was undetectable.

Everted gut sac technique for assessment of calcium transport. Under ether anesthesia, rats were dosed intrajugularly with various doses of vitamin $\mathrm{D}_{3}$ or vitamin $\mathrm{D}_{3} 3 \beta$-glucosiduronate in $50 \mu \mathrm{l}$ of $75 \%$ aqueous ethanol. Control rats were dosed with $75 \%$ aqueous ethanol alone. Before each dose, $400 \mu \mathrm{l}$ of blood was drawn to measure serum calcium or phosphorus levels. $24 \mathrm{~h}$ later, the rats were decapitated and their blood was collected. The first $10 \mathrm{~cm}$ of the duodenum was removed. Duodenal intestinal calcium transport was measured by the everted gut sac technique of Martin and DeLuca (10).

Duodenal organ culture. This was performed as described by Corradino (11). To detect the presence of $\beta$-glucuronidase in the system, $\left[{ }^{3} \mathrm{H}\right]$ tetrahydroaldosterone $3 \beta$-glucosiduronate (concentration $10,845 \mathrm{dpm} / \mathrm{ml}$ in water) was added to the medium. The absence of free tetrahydroaldosterone was detected by DEAE chromatography. Salts in the culture medium were removed by applying the solution to a $1 \times 25-\mathrm{cm}$ Amberlite XAD-2 (Rohm \& Haas Co., Philadelphia, Pa.) column; the water soluble salts were eluted with $150 \mathrm{ml}$ of water. Organic materials were subsequently eluted with $150 \mathrm{ml}$ of methanol. $10-\mathrm{ml}$ fractions were collected; radioactivity was measured in aliquots taken from the eluate. The methanolic fractions that had detectable radioactivity were collected, pooled, and dried on a flash evaporator. The resulting oily residue was subjected to DEAE batch elution chromatography. DEAEcellulose $(10 \mathrm{~g})$ was equilibrated in methanol. The residue was resuspended in methanol and applied to the gel. The gel was eluted with methanol $(100 \mathrm{ml})$ and later with $25 \%$ acetic acid in methanol $(100 \mathrm{ml})$. The solvents were evaporated and the radioactivity was determined.

Serum calcium and inorganic phosphorus measurements. Serum calcium or phosphorus were measured after appropriate doses of either vitamin $D_{3}$, vitamin $D_{3} 3 \beta$-glucosiduronate,

${ }^{1}$ Abbreviations used in this paper: $\mathrm{CaBP}$, calcium-binding protein; HPLC, high performance liquid chromatography; $\mathrm{M}^{+}$, parent molecular ion; $\mathrm{m} / \mathrm{e}$, mass/energy ratio. or vehicle by intravenous, intraperitoneal, or oral routes. Serum calcium was determined with an atomic absorption spectrometer (Perkin-Elmer Corp., Instrument Div., Norwalk, Conn.; model 303) using $0.1 \% \mathrm{LaCl}_{3}$ as diluent. Serum inorganic phosphorus was determined by a colorimetric assay (12).

25-Hydroxyvitamin D assay. The serum 25-hydroxyvitamin D levels were measured as previously described (13).

Statistical analysis. The statistical analysis were performed as described by Bancroft (14).

Synthesis of methyl(9,10-secocholesta-5,7,10[19]-trien-3 $\beta$ yl-2',3',4'-tri-O-acetyl- $\beta$-D-glucopyranosid)uronate. $1 \mathrm{~g} \mathrm{(3.63}$ mmol) of freshly prepared (15) silver carbonate and $0.159 \mathrm{~g}$ $(0.413 \mathrm{mmol})$ of vitamin $D_{3}$ were suspended in dry benzene $(20 \mathrm{ml})$ in a distillation flask. Distillation was commenced and as the benzene distilled, a solution of $0.518 \mathrm{~g}(1.30 \mathrm{mmol})$ of methyl 1-bromo-2,3,4-tri-O-acetyl-1-deoxy- $\beta$-D-glucuronate (16) in dry benzene $(25-30 \mathrm{ml})$ was added at the same rate as the rate of distillation. After addition of about half of the bromide solution, an additional $1 \mathrm{~g}(3.63 \mathrm{mmol})$ of dried silver carbonate was added to the reaction mixture. The reaction was followed by thin-layer chromatography; when the reaction was complete, the reaction flask was cooled, the silver salt was filtered and washed with an additional quantity (2 $\times 15 \mathrm{ml}$ ) of dry benzene. The filtrate and the washings were combined, dried over anhydrous sodium sulfate and the solvent was removed on a rotary evaporator. The residual oil was chromatographed on a silica gel $60 \mathrm{H}$ column (Merck AG, Darmstadt, West Germany) with $10 \%$ ether-hexane as the eluting solvent. The unreacted bromide was separated from the product, and the latter was recrystallized from hot ethanol. The yield was $85-90 \%$. The melting point of the product was $72^{\circ}-73^{\circ} \mathrm{C}$; UV spectrometry showed $\lambda$ maximum at $265 \mathrm{~nm}$ and $\lambda$ minimum at $228 \mathrm{~nm}$.

The mass spectrum contains a peak for parent molecular ion at mass/energy $(\mathrm{m} / \mathrm{e}) 700\left(\mathrm{M}^{+}\right)$and peaks at 383 (M-pyronium ion $)^{+}, 366\left(\mathrm{M} \text {-pyronium ion- } \mathrm{H}_{2} \mathrm{O}\right)^{+}$. Peaks at $\mathrm{m} / \mathrm{e} 317$ (pyronium ion) ${ }^{+}, 257\left(\mathrm{C}_{11} \mathrm{H}_{13} \mathrm{O}_{7}\right)^{+}, 155\left(\mathrm{C}_{7} \mathrm{H}_{7} \mathrm{O}_{4}\right)^{+}, 95\left(\mathrm{C}_{5} \mathrm{H}_{3} \mathrm{O}_{2}\right)^{+}, 60$ (methyl formate or acetic acid $)^{+}$establish the presence of triacetylated sugar moiety (Fig. 1).

Preparation of vitamin $D_{3} 3 \beta$-glucosiduronate (sodium 9,10secocholesta-5,7,10[1.9]trien-3-yl- $\beta$-D-glucopyranosiduronate) (17). To a solution of $100 \mathrm{mg}(0.143 \mathrm{mmol})$ of methyl-(9,10secocholesta-5,7,10[19]-trien-3 $\beta$-yl-2', $3^{\prime}, 4^{\prime}$-tri- $O$-acetyl- $\beta$-Dglucopyranosid)uronate in $10 \mathrm{ml}$ of $1: 1$ mixture of anhydrous methanol and dichloromethane, $1 \mathrm{ml}$ of $0.1 \mathrm{~N}$ sodium hydroxide in anhydrous methanol was added. After 2-h stirring at room temperature $20 \mathrm{ml}$ of distilled tetrahydrofuran was added. After this, aqueous sodium hydroxide $(10 \mathrm{ml}, 1 \mathrm{~N})$ was added over a period of $10 \mathrm{~min}$. The mixture was stirred for 30 min when, an oily semisolid material appeared; the latter 
was dissolved by the addition of $20 \mathrm{ml}$ of methanol. The water was removed from the flask and the mixture was allowed to react for an additional 30-45 $\mathrm{min}$. The solvent was concentrated until all the organic solvent was removed and an oily semi-solid reappeared in the reaction mixture. The semi-solid was washed several times with water $(10 \mathrm{ml})$. The oily material was dissolved in methanol and a foamy solid was obtained on evaporation of the solvent.

Purification of vitamin $D_{3} 3 \beta$-glucosiduronate. The foamy solid obtained in the above experiment was further purified on an HPLC system using acetonitrile-water $(1: 1.86)$ as the starting solvent. A linear gradient was developed over a period of $15 \mathrm{~min}$ at a flow rate of $2 \mathrm{ml} / \mathrm{min}$. The final eluent was $100 \%$ acetonitrile. The HPLC profile of the title compound is shown in Fig. 2. The ultraviolet spectrum of vitamin $D_{3}$ glucosiduronate (Fig. 3) exhibited a curve expected of the vitamin D chromophore with an absorbance maximum at $265 \mathrm{~nm}$ and an absorbance minimum at $228 \mathrm{~nm}$. The ratio of 1.68 for absorbance maximum/

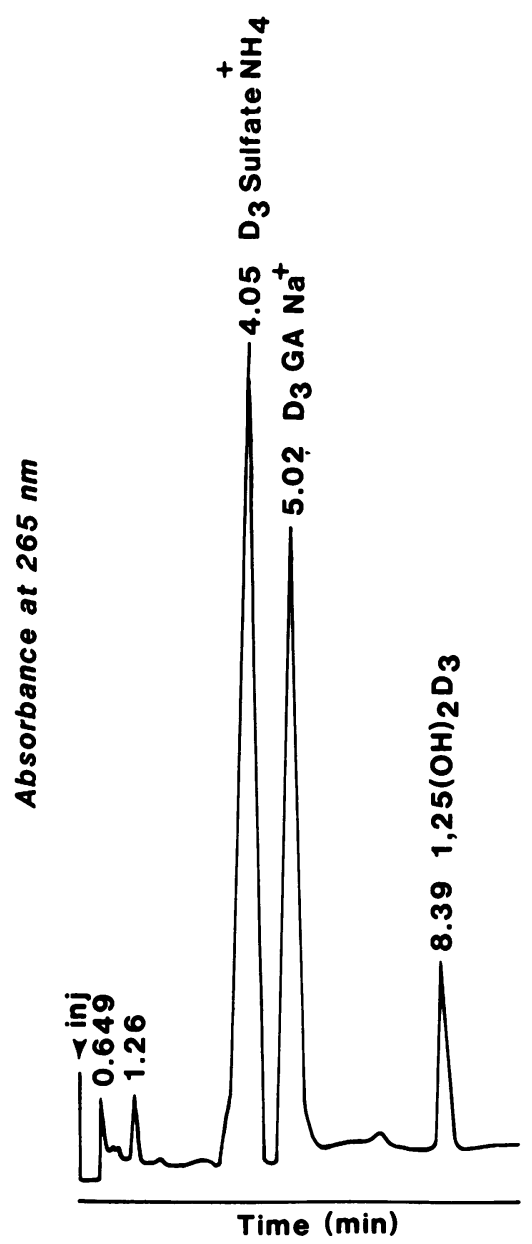

FIGURE 2 Reverse phase HPLC of vitamin $\mathrm{D}_{3}$ conjugates, 0.4 $\times 30 \mathrm{~cm} \mu$ Bondapak column, 35:65 ( vol/vol) acetonitrile/water to $100 \%$ acetonitrile with a linear gradient in $15 \mathrm{~min}$. Ammonium vitamin $\mathrm{D}_{3}$ sulfate $(4.05 \mathrm{~min})$. Vitamin $\mathrm{D}_{3} 3 \beta$-glucosiduronate $(5.02 \mathrm{~min})$ and 1,25-dihydroxyvitamin $\mathrm{D}_{3}(8.39 \mathrm{~min})$.

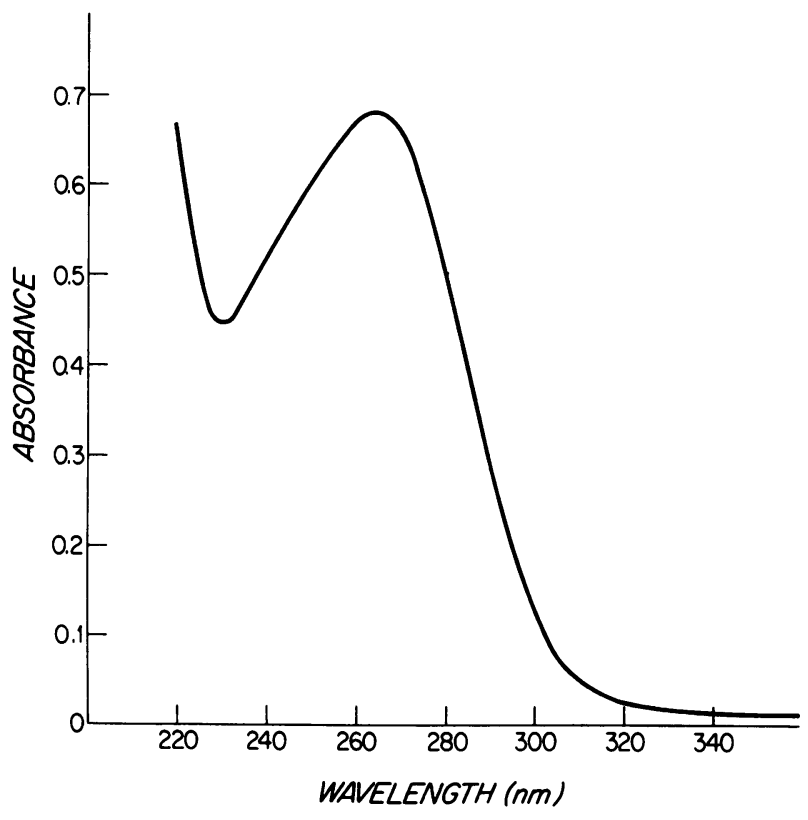

FIgURE 3 Ultraviolet spectra of vitamin $D_{3} 3 \beta$-glucosiduronate. $\lambda$ maximum, $265 \mathrm{~nm} ; \lambda$ minimum $228 \mathrm{~nm}$. $\lambda$ maximum/ minimum is 1.68 .

absorbance minimum is also characteristic of the triene chromophore in vitamin $D$. The molecular ion peak is not observed in the mass spectra; however, peaks at $\mathrm{m} / \mathrm{e} 446\left(\mathrm{M}^{+}-\right.$ side chain), $366\left(\mathrm{M}^{+}\right.$-sugar moiety $\left.-\mathrm{H}_{2} \mathrm{O}\right), 177\left(\mathrm{C}_{6} \mathrm{H}_{8} \mathrm{O}_{6}\right)^{+} 133$ $\left(\mathrm{C}_{5} \mathrm{H}_{8} \mathrm{O}_{4}\right)^{+}, 118\left(\mathrm{C}_{4} \mathrm{H}_{6} \mathrm{O}_{4}\right)^{+}, 74\left(\mathrm{C}_{3} \mathrm{H}_{6} \mathrm{O}_{2}\right)^{+}, 73\left(\mathrm{C}_{3} \mathrm{H}_{5} \mathrm{O}_{2}\right)^{+}$, and 55 $\left(\mathrm{C}_{3} \mathrm{H}_{3} \mathrm{O}\right)^{+}$are in agreement with the proposed structure for vitamin $\mathrm{D}_{3}$ glucosiduronate (Fig. 4).

Synthesis of vitamin $D_{3} 3 \beta$-sulfate (ammonium 9,10-secocholesta-5,7,10(19)-triene-3-yl- $\beta$-sulfate). Vitamin $\mathrm{D}_{3} 3 \beta$ sulfate was prepared according to the procedure of Higaki et al. (18). It was used as a standard for the HPLC of vitamin $\mathrm{D}$ conjugates.

\section{RESULTS}

We tested the biological activity of vitamin $D_{3}$ and vitamin $\mathrm{D}_{3} 3 \beta$-glucosiduronate after intravenous, intraperitoneal, and oral dosing. When vitamin $D_{3}$ or vitamin $D_{3} 3 \beta$-glucosiduronate was administered intravenously, to rats maintained on a low calcium diet, an increase in serum calcium was observed $24 \mathrm{~h}$ after the dose. Table I shows the mean differences of serum calcium levels $(\bar{\Delta})$ measured before and after treatment, the results of two-tailed $t$ test values along with the significance of these tests (14). Vitamin $D_{3}$ is active at all the doses tested, whereas vitamin $D_{3} 3 \beta$-glucosiduronate is active only at doses of 1,000 pmol or more. When the biological activity of vitamin $\mathrm{D}_{3}$ and vitamin $\mathrm{D}_{3} 3 \beta$-glucosiduronate was tested in an everted duodenal gut sac system, both compounds were noted to increase active calcium transport (Table II). It is ap- 


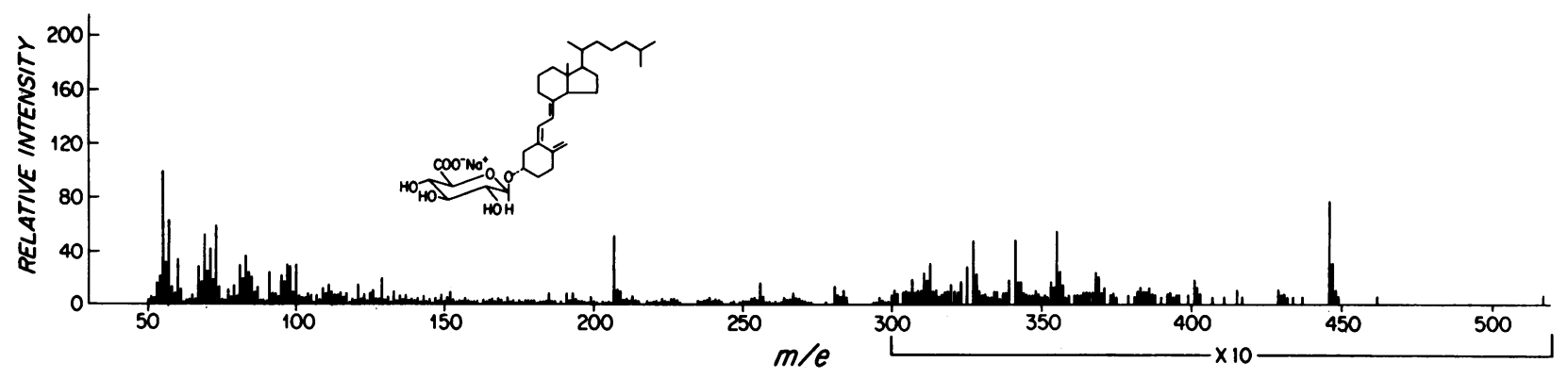

FIgURE 4 Mass spectrum of vitamin $D_{3} 3 \beta$-glucosiduronate.

parent that vitamin $D_{3} 3 \beta$-glucosiduronate has intrinsic biologic activity but is less potent than vitamin $D_{3}$ itself at all doses tested.

When vitamin $\mathrm{D}$-deficient rats were administered a dose of $1,300 \mathrm{pmol} / \mathrm{d}$ for $7 \mathrm{~d}$ of either ethanol, vitamin

TABLE I

Increse in Serum Calcium in Response to Various Doses of Vitamin $D_{3}$ or Vitamin $D_{3}$ Glucosiduronate

\begin{tabular}{|c|c|c|c|c|}
\hline \multirow[b]{2}{*}{ Compound } & \multirow[b]{2}{*}{ Dosage } & \multirow[b]{2}{*}{$\begin{array}{l}\text { Rats/ } \\
\text { group }\end{array}$} & \multicolumn{2}{|c|}{ Serum calcium } \\
\hline & & & $\bar{\Delta} \pm \mathrm{SE}$ & $\begin{array}{l}\text { Signifi- } \\
\text { cance* }^{*}\end{array}$ \\
\hline & pmol/rat & & $m g / 100 \mathrm{ml}$ & $P$ \\
\hline Control & - & 5 & $0.04 \pm 0.26$ & NS \\
\hline \multirow[t]{8}{*}{ Vitamin $D_{3}$} & 65 & 5 & $0.66 \pm 0.30$ & $<0.025$ \\
\hline & 260 & 6 & $1.65 \pm 0.17$ & $<0.001$ \\
\hline & 325 & 7 & $1.16 \pm 0.31$ & $<0.005$ \\
\hline & 650 & 6 & $1.28 \pm 0.37$ & $<0.01$ \\
\hline & 1,040 & 5 & $1.42 \pm 0.18$ & $<0.001$ \\
\hline & 1,300 & 7 & $1.51 \pm 0.31$ & $<0.01$ \\
\hline & 2,600 & 5 & $1.96 \pm 0.21$ & $<0.001$ \\
\hline & 52,000 & 5 & $2.26 \pm 0.18$ & $<0.001$ \\
\hline \multirow{8}{*}{$\begin{array}{l}\text { Vitamin } \mathrm{D}_{3} \\
\text { glucosiduronate }\end{array}$} & 65 & 5 & $-0.08 \pm 0.25$ & NS \\
\hline & 260 & 6 & $0.00 \pm 0.27$ & NS \\
\hline & 325 & 7 & $-0.24 \pm 0.15$ & NS \\
\hline & 650 & 7 & $0.39 \pm 0.15$ & $<0.025$ \\
\hline & 1,040 & 4 & $0.90 \pm 0.11$ & $<0.001$ \\
\hline & 1,300 & 9 & $0.48 \pm 0.22$ & $<0.05$ \\
\hline & 2,600 & 4 & $0.95 \pm 0.35$ & $<0.05$ \\
\hline & 52,000 & 5 & $1.68 \pm 0.15$ & $<0.001$ \\
\hline
\end{tabular}

Rats fed a vitamin D-deficient, low calcium synthetic diet for $4 \mathrm{wk}$ were administered various doses of either vitamin $D_{3}$ or vitamin $D_{3} 3 \beta$-glucosiduronate in $50 \mu$ l of $75 \%$ aqueous ethanol intrajugularly. Rats in the control group received only $75 \%$ ethanol. Before the dose, $400 \mu$ l of blood was drawn and serum calcium determined. $24 \mathrm{~h}$ later rats were killed and blood was collected for calcium determination. The difference in the posttreatment and pretreatment $(\bar{\Delta})$ is shown.

* $P$ values for $t$ test comparing the after treatment vs. before treatment. NS means not significant.
$D_{3}$, or vitamin $D_{3} 3 \beta$-glucosiduronate intraperitoneally, the change in serum calcium (mean $\pm \mathrm{SE}$ ) was 0.72 $\pm 0.19 \mathrm{mg} / \mathrm{dl}$ in the control group, $2.52 \pm 0.22 \mathrm{mg} / \mathrm{dl}$ in the vitamin $D_{3}$-dosed group, and $1.69 \pm 0.18 \mathrm{mg} / \mathrm{dl}$ in the vitamin $D_{3} 3 \beta$-glucosiduronate-treated group. Both

TABLE II

Intestinal Calcium Transport in Response to Various Doses of Vitamin $D_{3}$ or Vitamin $D_{3}$ Glucosiduronate

\begin{tabular}{lrcc}
\hline \multicolumn{1}{c}{ Compound } & Dosage & $\begin{array}{c}\text { Intestinal calcium } \\
\text { transport* }\end{array}$ & Significance \\
\hline & pmol/rat & serosal/mucosal ratio & $P$ \\
Control & & $1.05 \pm 0.07$ & \\
Vitamin $D_{3}$ & 65 & $2.62 \pm 0.11$ & $<0.025$ \\
& 260 & $3.39 \pm 0.37$ & $<0.001$ \\
& 325 & $3.23 \pm 0.11 \S$ & $<0.001$ \\
& 650 & $2.80 \pm 0.39 \S$ & $<0.01$ \\
& 1,040 & $4.08 \pm 0.27$ & $<0.001$ \\
& 1,300 & $3.28 \pm 0.34 \$$ & $<0.001$ \\
& 2,600 & $2.24 \pm 0.29$ & $<0.005$ \\
& 52,000 & $5.92 \pm 1.63$ & $<0.001$ \\
& & & \\
Vitamin $D_{3}$ & 65 & $1.61 \pm 0.19$ & $<0.05$ \\
glucosiduronate & 260 & $1.18 \pm 0.25$ & $\mathrm{NS}$ \\
& 325 & $1.50 \pm 0.13$ & $\mathrm{NS}$ \\
& 650 & $1.94 \pm 0.31$ & $\mathrm{NS}$ \\
& 1,040 & $2.57 \pm 0.51$ & $<0.02$ \\
& 1,300 & $2.78 \pm 0.36$ & $<0.01$ \\
& 2,600 & $3.31 \pm 0.57$ & $<0.005$ \\
& 52,000 & $5.36 \pm 0.92$ & $<0.005$ \\
& & &
\end{tabular}

Rats fed a vitamin D-deficient synthetic, low calcium diet were administered either compound in $50 \mu \mathrm{l}$ of $75 \%$ aqueous ethanol intrajugularly; the control group received only aqueous ethanol. $24 \mathrm{~h}$ later the rats were killed and their duodena were removed. Intestinal calcium transport was measured.

* Mean \pm SE.

$\ddagger P$ values for two-tailed $t$ test. Control vs. the treatment. NS means not significant.

\$ These groups have a separate control with a serosal/ mucosal of $1.49 \pm 0.12$. 
TABLE III

Relative Potencies of 1,25-Dihydroxyvitamin $D_{3}$, Vitamin $D_{3}$ and Vitamin $D_{3} 3 \beta$-Glucosiduronate in the Induction of $C a B P$ in the Organ-cultured Duodenum

\begin{tabular}{cccc}
\hline $1 \alpha, 25(\mathrm{OH})_{2} \mathrm{D}_{3}$ & Vitamin $\mathrm{D}_{3}$ & $\begin{array}{c}\text { Vitamin } \mathrm{D}_{3}-3 \beta- \\
\text { glucosiduronate }\end{array}$ & CaBP (mean) \\
\hline$n M$ & $\mu M$ & $\mu M$ & $\mu g / 100$ mg duodenum \\
0 & 0 & 0 & 0 \\
0.065 & - & - & 1.02 \\
0.65 & - & - & $3.81^{*}$ \\
6.5 & - & - & 12.88 \\
- & 0.065 & - & 1.00 \\
- & 0.65 & - & $3.25 \ddagger$ \\
- & 6.5 & - & 10.07 \\
- & - & 0.065 & 0 \\
- & - & 0.65 & 0 \\
- & - & 6.5 & 0 \\
\hline
\end{tabular}

CaBP was determined in the embryonic chick duodena after various concentrations of vitamin $\mathrm{D}$ homologue compounds were separately introduced into the medium. The details of the procedure are described elsewhere (11).

* Fits a power function: $y=422,106 \times 0.55 ; r=0.99$.

$\ddagger$ Fits a power function: $y=4,054 \times 0.5 ; r=0.99$.

treatment groups were significantly different from the control $(P<0.001)$. Again vitamin $D_{3} 3 \beta$-glucosiduronate showed less activity than vitamin $\mathrm{D}_{3}$.

When rats were administered an oral dose of 5,000 $\mathrm{pmol} / \mathrm{d}$ of either vitamin $\mathrm{D}_{3}$ or vitamin $\mathrm{D}_{3} 3 \beta$-glucosiduronate for $4 \mathrm{~d}$, intestinal serosal/mucosal ratios were elevated in both the vitamin $D_{3}$ and vitamin $D_{3} 3 \beta$ glucosiduronate-treated rats. The serosal/musocal ratio for the control group was $($ mean $\pm S E$ ) $1.09 \pm 0.17$, for the vitamin $\mathrm{D}_{3}$-treated group the corresponding figure was $3.68 \pm 0.25$, and for the vitamin $D_{3} 3 \beta$-glucosiduronate group it was $3.63 \pm 0.56(P<0.001$ for both treatment groups when compared with control). However, serum calcium increased only in the vitamin $\mathrm{D}_{3}$-treated group (control $\bar{\Delta} \pm \mathrm{SE}, 0.74 \pm 0.17 \mathrm{mg} / \mathrm{dl}$, vitamin $\mathrm{D}_{3} 1.66$ $\pm 0.42 \mathrm{mg} / \mathrm{dl}$, and vitamin $\mathrm{D}_{3} 3 \beta$-glucosiduronate 0.80 $\pm 0.15 \mathrm{mg} / \mathrm{dl}$ ).

Table III summarizes the results of the biopotency of 1,25-dihydroxyvitamin $\mathrm{D}_{3}$, vitamin $\mathrm{D}_{3}$, and vitamin $\mathrm{D}_{3} 3 \beta$-glucosiduronate in embryonic chick duodena. The activity of vitamin $D_{3} 3 \beta$-glucosiduronate, determined by measuring the concentration of vitamin $D$ induced calcium binding protein $(\mathrm{CaBP})$, was zero at a concentration as high as $6.5 \mu \mathrm{M}$. Both vitamin $\mathrm{D}_{3}$ and 1,25-dihydroxyvitamin $D_{3}$ showed the expected responses. No hydrolysis of tetrahydroaldosterone $3 \beta$ glucosiduronate was detected in this system.

In animals maintained on a low phosphorus diet and dosed with either vitamin $D_{3}$ or vitamin $D_{3} 3 \beta$-glucosiduronate at doses of $5,000 \mathrm{pmol} / \mathrm{d}$ intraperitoneally
TABLE IV

Serum 25-Hydroxyvitamin D Levels in Vitamin D-deficient Rats

\begin{tabular}{lcc}
\hline & Dose administered & 25-Hydroxyvitamin $\mathrm{D}^{*}$ \\
\hline & $m m o l$ & $n g / d l$ \\
Control & - & $4.18 \pm 2.65$ \\
Vitamin $\mathrm{D}_{3}$ & 1,040 & $12.65 \pm 2.05$ \\
& 2,600 & $17.95 \pm 0.75$ \\
& 52,000 & $72.76 \pm 8.85$ \\
Vitamin $\mathrm{D}_{3}$ & 1,040 & $8.83 \pm 0.66$ \\
glucosiduronate & 2,600 & $9.29 \pm 0.69$ \\
& 52,000 & $26.05 \pm 2.01$ \\
\hline
\end{tabular}

Rats were fed with vitamin D-deficient low calcium diets for 4 wk. Rats were dosed with various doses of vitamin $D_{3}$ or vitamin $D_{3} 3 \beta$-glucosiduronate intrajugularly. $24 \mathrm{~h}$ later, the blood was collected. Serum 25-hydroxyvitamin D levels were determined in duplicate or triplicate.

* Mean $\pm \mathrm{SE}$.

for $4 \mathrm{~d}$, serum phosphorus increased in the vitamin $\mathrm{D}_{3}$-treated group $(6.49 \pm 1.0 \mathrm{vs} .4 .4 \pm 0.9 \mathrm{mg} / \mathrm{dl}$ in controls, mean $\pm \mathrm{SE}$ ), but only slightly in the vitamin $\mathrm{D}_{3}$ $3 \beta$-glucosiduronate-treated group $(5.04 \pm 1.1$ vs. $4.4 \pm 0.9$ $\mathrm{mg} / \mathrm{dl}$ in controls).

Serum 25-hydroxyvitamin $\mathrm{D}_{3}$ levels were measured in control rats and in rats administered varying doses of either vitamin $D_{3}$ or vitamin $D_{3} 3 \beta$-glucosiduronate $24 \mathrm{~h}$ before sacrifice (Table IV). Serum 25-hydroxyvitamin D levels are higher in animals administered vitamin $\mathrm{D}_{3}$ than those of animals administered an equimolar amount of vitamin $D_{3}$ glucosiduronate.

\section{DISCUSSION}

Bell and Kodicek (7) demonstrated that products of radiolabeled vitamin $D_{3}$ are excreted in rat bile. They suggested one of these compounds could be vitamin $D_{3} 3 \beta$-glucosiduronate. More recent work from our laboratory has demonstrated that both 1,25-dihydroxyvitamin $D_{3}(5)$ and 24,25-dihydroxyvitamin $D_{3}(6)$ metabolites are excreted in the bile of rats and it is likely that 1,25-dihydroxyvitamin $D_{3}$ glucosiduronate is present in rat bile. From these and other studies (5-9), it is clear that vitamin D metabolite(s) are excreted into the bile and reabsorbed in the intestine. This process of reabsorption would be of little value to the organism (other than an excretory route) unless the organism could in some way reutilize the excreted material. We have shown in the present studies that one such compound, vitamin $D_{3} 3 \beta$-glucosiduronate, has biological activity. When a single dose of vitamin $D_{3} 3 \beta$ glucosiduronate or vitamin $D_{3}$ is administered intra- 
jugularly to vitamin $\mathrm{D}$ and calcium-deficient rats, the serum calcium and intestinal serosal/mucosal ratios increase at all doses of vitamin $D_{3}$ and at a dose of 1,000 pmol or higher for vitamin $\mathrm{D}_{3} 3 \beta$-glucosiduronate. Based upon these results, vitamin $\mathrm{D}_{3} 3 \beta$-glucosiduronate is considerably less active than vitamin $\mathrm{D}_{3}$ in vivo. Similar results were obtained when $1,300 \mathrm{pmol} / \mathrm{d}$ of either compound was administered intraperitoneally to vitamin D-deficient rats for a week. When an oral dose of $5,000 \mathrm{pmol} / \mathrm{d}$ for $4 \mathrm{~d}$ of either vitamin $D_{3}$ or vitamin $\mathrm{D}_{3} 3 \beta$-glucosiduronate was administered, no mobilization of calcium from bone was observed for the vitamin $\mathrm{D}_{3} 3 \beta$-glucosiduronate-treated group, whereas this compound was just as active as vitamin $D_{3}$ itself with respect to its capacity to stimulate calcium transport in everted gut sacs. Serum inorganic phosphorus increased after chronic dosing with vitamin $\mathrm{D}_{3}$ but to a lesser extent in animals dosed with equimolar amounts of vitamin $\mathrm{D}_{3} 3 \beta$-glucosiduronate.

The mode of action of vitamin $\mathrm{D}_{3} 3 \beta$-glucosiduronate is most likely due to hydrolysis to the free sterol. The glucosiduronate may be hydrolyzed either in the biliary tract, in the intestine or in other tissues by $\beta$-glucuronidases. The aglycon, vitamin $D_{3}$, released by such enzymatic hydrolysis would then be utilized in the normal fashion. The location of the vitamin $\mathrm{D}_{3} 3 \beta$-glucuronidase is unclear at present. Even though rat bile contains $\beta$-glucuronidase (19), it appears that the hydrolysis does not take place to a great extent in bile as only small quantities of free sterol were found in rat bile (5). However, endogenous intestinal cell glucuronidases and/or bacterial glucuronidases may play an important, though unproved, role in the formation of the free sterol. $\beta$-Glucuronidase in other tissues may also play a significant role. It is unlikely that the intact conjugate is biologically active because it fails to increase CaBP synthesis in an embryonal duodenal system at doses several orders of magnitude higher than the dose of vitamin $\mathrm{D}_{3}$ necessary to elicit such a response. A model radiolabeled conjugate, tetrahydroaldosterone $3 \beta$-glucosiduronate, is not hydrolyzed and hence, it is unlikely that vitamin $D_{3} 3 \beta$-glucosiduronate undergoes hydrolysis in this organ culture system. These data would suggest that the intact sterol conjugate is inactive. Further evidence supporting the necessity of hydrolysis of the conjugate to the free sterol is the appearance of 25hydroxyvitamin $\mathrm{D}$ in the serum after a dose of the conjugate. The increment in serum 25-hydroxyvitamin $D_{3}$ levels is in accordance with the observed activity of the conjugate relative to vitamin $\mathrm{D}_{3}$. Thus, it is likely that the conjugate is biologically inactive unless it undergoes hydrolysis to release the active aglycon, vitamin $D_{3}$, which is in turn metabolized to 25-hydroxyvitamin $\mathrm{D}_{3}$ and 1,25-dihydroxyvitamin $\mathrm{D}_{3}$.

Our data lead us to believe that the conjugation and excretion of vitamin $D_{3} 3 \beta$-glucosiduronate in bile may not merely be an excretory process. The conjugate may be reutilized, most likely by hydrolysis to the free sterol. It is likely, though unproved at present, that other glucosiduronates of vitamin $\mathrm{D}_{3}$ homologues may also be reutilized in this manner. In any event, were defects in the hydrolysis and reutilization of the conjugates of vitamin $\mathrm{D}_{3}$ homologues to occur in organs such as the intestine, it is possible that less vitamin $D_{3}$ would be available for utilization by the organism. We speculate that such a situation could arise in diseases associated with a decreased intestinal transit time; in this situation there may be inadequate time available for $\beta$-glucuronidases to hydrolyze substrate. Alternatively, there may be a decrease in the amount of $\beta$-glucuronidase present. It is possible that alterations in this process could contribute, in part, to the vitamin D deficiency seen in hepatic and intestinal disease.

\section{ACKNOWLEDGMENTS}

This work was supported, in part, by grants to Dr. Kumar from R. K. Mellon Foundation, and the National Institutes of Health grants AM 25409 and AM 26808.

\section{REFERENCES}

1. DeLuca, H. F. 1979. Vitamin D system in the regulation of calcium and phosphorus metabolism. W. O. Atwater Memorial Lecture. Nutr. Rev. 37: 161-193.

2. Kumar, R., H. K. Schnoes, and H. F. DeLuca. 1978. Rat intestinal 25 -hydroxyvitamin $\mathrm{D}_{3}$ and $1 \alpha, 25$-dihydroxyvitamin $\mathrm{D}_{3}$-24-hydroxylase. J. Biol. Chem. 253: 3804-3809.

3. Friedlander, E. J., and A. W. Norman. 1975. Studies on the Metabolism of calciferol X11. Production in vitro of 1,24,25- $(\mathrm{OH})_{3}$-vitamin $\mathrm{D}_{3}$ and a search for its occurrence in vivo. Arch. Biochem. Biophys. 170: 731-738.

4. Kumar, R., D. H. Harnden, and H. F. DeLuca. 1976. Metabolism of 1,25-dihydroxyvitamin $\mathrm{D}_{3}$ : evidence for side chain oxidation. Biochemistry. 15: 2420-2423.

5. Kumar, R., S. Nagubandi, V. R. Mattox, and J. M. Londowski. 1980. Enterohepatic physiology of 1,25-dihydroxyvitamin $\mathrm{D}_{3}$.J. Clin. Invest. 65: 277-284.

6. Kumar, R., S. Nagubandi, and J. M. Londowski. 1980. The enterohepatic physiology of 24,25-dihydroxyvitamin $\mathrm{D}_{3}$. J. Lab. Clin. Med. 96: 278-284.

7. Bell, P. A., and E. Kodicek. 1969. Investigations on the metabolites of vitamin $D$ in rat bile. Separation and partial identification of a major metabolite. Biochem. J. 115: 663-669.

8. Arnaud, S. B., R. S. Goldsmith, P. W. Lambert, and V. L. W. Go. 1975. 25-hydroxyvitamin $\mathrm{D}_{3}$ : evidence of an enterohepatic circulation in man. Proc. Soc. Exp. Biol. Med. 149: 570-572.

9. Avioli, L. V., S. W. Lee, J. MacDonald, J. E. Lund, and H. F. DeLuca. 1967. Metabolism of vitamin $\mathrm{D}_{3^{3}}{ }^{3} \mathrm{H}$ in human subjects: distribution in blood, bile, feces and urine. J. Clin. Invest. 46: 983-992.

10. Martin, D. L., and H. F. DeLuca. 1969. Influence of sodium on calcium transport by the rat small intestine. $\mathbf{A m}$. J. Physiol. 216: 1351-1359. 
11. Corradino, R. A. 1978, Calcium binding protein of intestine: Induction by biologically significant cholecalciferollike steroids in vitro. J. Steroid Biochem. 9: 1183-1187.

12. Chen, P. A., Jr., T. Y. Toribara, and H. Warner. 1956. Microdetermination of phosphorus. Anal. Chem. 28: 1756-1758.

13. Kumar, R., W. R. Cohen, P. Silva, and F. H. Epstein. 1979. Elevated 1,25-dihydroxyvitamin D plasma levels in normal human pregnancy and lactation. J. Clin. Invest. 63: 342-344.

14. Bancroft, T. A. 1968. Topics in Intermediate Statistical Methods. Iowa State University Press, Ames, Iowa. 1: 342.

15. Becker, J. F. 1965. Steroid glucuronides. I. The synthesis of $\beta$-D-glucopyranosiduronic acids of 3-hydroxy-androstane-17-ketones. Biochim. Biophys. Acta. 100: 574-581.

16. Bollenback, G. N., J. W. Long, D. G. Benjamin, and J. A. Lindquist. 1955. The synthesis of Aryl-D-glucopyranosiduronic acids. J. Am. Chem. Soc. 77: 3310-3315.

17. Scheider, J. J., and N. S. Bhacca. 1969. Synthesis and characterization of cholesterol $\beta$-D-glucuronide and derivatives. J. Org. Chem. 34: 1990-1993.

18. Higaki, M., M. Takahashi, T. Suzuki, and Y. Sahashi. 1965. Metabolic activities of vitamin D in animals. III Biogenesis of vitamin D sulfate in animal tissues. J. Vitaminol. (Kyoto). 11: 261-265.

19. Ho, K. J., L. C. Ho, and O. R. Kruger. 1979. Characterization and determination of the activity of biliary $\beta$-glucuronidase in rats. J. Lab. Clin. Med. 93: 916-925. 